\title{
COMPETENCIES AND ROLES OF A SOCIAL CURATOR IN WORKING WITH RISKY YOUTH AND CRISIS INTERVENTION

\author{
Boris Pták ${ }^{1}$, Soňa Šrobárová ${ }^{2}$ Zuzana Gejdošová $^{3}$
}

\begin{abstract}
The terms crisis and crisis intervention are a very wide-ranging issue, which is why we focused on social curators and field social workers working at the Department of Social and Legal Protection of Children and Social Guard in the Slovak Republic. Specifically, their perception and use of crisis intervention methods in practice. The aim was to find out the perception of social curators and field social workers of social protection, their use of crisis intervention methods in practice. In the framework of the researched issue, we present detailed results on the established relationships between the variables studied in relation to the theoretical knowledge and the findings of previous research in this area.
\end{abstract}

UDC Classification: 304, DOI: 10.12955/cbup.v7.1424

Keywords: Crisis, Socio-legal protection and curate, Risky youth

\section{Introduction}

Social-legal protection of children and social curate (hereinafter referred to as SPoCaSC) in legislation of the Slovak Republic has recently undergone significant changes related to the amended Family Act, the amended Act on Social and Legal Protection of Children and Social Curator and other acts. It is clear from the statistical indicators of the Central Office of Labor, Social Affairs and Family that the number of children and youth to whom social guardianship measures are not given are rising, especially within the prevalence of youth. From a gender perspective, risk behavior is significantly higher in boys than in girls. Based on the total number of social curators at the Department of Social and Legal Protection of Children and Social Guard, which was 108 in 2016, on average, they each are assigned up to 140 children (families) per employee. With such a high number, it is clear that measures for the social and legal protection of children and social guardianship cannot be sufficiently enacted.

\begin{tabular}{|l|l|}
\hline Table 1: Reasons for the implementation of social care for children in 2016 \\
\hline Reasons & Number of children \\
\hline Criminal activity & 2046 \\
\hline Otherwise criminal activity & 710 \\
\hline Assistance and protection in infringement proceedings & 3534 \\
\hline Neglect of compulsory education & 5747 \\
\hline Behavioral disorders & 1523 \\
\hline Disturbed relationships & 552 \\
\hline Experimenting and drug addiction & 193 \\
\hline Other addiction & 17 \\
\hline Other & 25 \\
\hline Source: Annual Report V12 - Ministry of Labor, Social Affairs and Family, 2016 \\
\hline
\end{tabular}

Bednárik $(2013,2015$, and 2017) also draws attention to the problematic areas of social guardianship. They are advised of the insufficient network of facilities in which measures can be implemented, the problems of treatment and placement of a child with compulsory school attendance in detoxification and subsequent treatment, long-term practices (insufficient use of law possibilities). The samelow effectiveness of educational measures in socially and economically backward families, as long as the measures do not affect the family's financial income. For example issues related to the reduction of criminal liability to imprisonment and custody, the absence of their own educational and social programs or the involvement of accredited institutions.

The competences and roles of a social curator in working with at-risk youth are covered by the Act on Social and Child Protection and Social Courier. The problem, however, is the real-life fulfillment of these tasks, which should lead to the complete elimination of risk behavior. Their realization is possible only with the help of the effective functioning of the whole multidisciplinary team, which, through its consistent work, can achieve the goals set by the target group. In 2016, social guardianship measures were provided for 4876 adults, of which 468 were women, representing less than $10 \%$ of the total. The

\footnotetext{
${ }^{1}$ Catholic university in Ružomberok, Ružomberok, Slovakia, boris.ptak@ku.sk

${ }^{2}$ Catholic university in Ružomberok, Ružomberok, Slovakia, sona.srobarova@gmail.com

${ }^{3}$ Catholic university in Ružomberok, Ružomberok, Slovakia, zuzana.gejdosova@ku.sk
} 
most common reasons for providing social guardianship (3/4) were release from prison, conditional release from prison or release from custody.In view of the high number of people in this category, it would be appropriate to specify these reasons in the future.

Other reasons also include aid for long-term unemployment, assistance with housing search, participation in probation, drug addiction, etc.

\begin{tabular}{|l|l|}
\hline Table 2 The most common reasons for conducting social guardianship for adults in 2016 \\
\hline Reasons & Number \\
\hline Discharge from prison & 2985 \\
\hline Conditional release from prison & 842 \\
\hline Release from custody & 171 \\
\hline Long-term unemployment & 119 \\
\hline Helping to find housing & 83 \\
\hline Participation in probation & 73 \\
\hline Other & 1161 \\
\hline
\end{tabular}

Source: Annual Report V12 - Ministry of Labor, Social Affairs and Family, 2016

\section{Personality of social worker performing SPoCaSC measures with risky youth}

"The personality of a social worker is based on quality education, social outlook, an integrated character set (honesty, justice, truthfulness, diligence, arousing people's confidence), professional assumptions and abilities, ability to communicate with clients, institutions and social organizations" (Gabura, 2012). In order for a social worker to practice his profession effectively, he should be congruent, empathetic, authentic, and unconditionally accept every client as he really is.

Congruence expresses such a state of our being when we are ourselves without having to present a certain facade. We don't have to hide behind a mask or a professional role. When a social worker is congruent, his inner feelings are expressed in his behavior, and so others perceive him as he really is. But this does not mean that all these feelings should manifest or express every thought that comes to him. If that were the case, there would be a risk that he would shift the attention from the client to himself. Congruence means creating a relationship with the client When this relationship is well established, not only the client but also the social worker grows in it. Mátel (2013) understands congruence as a state of personality, when the behavior of the individual is consistent with the perception of oneself. The counselor is aware of the feelings he is experiencing and is able to show them. Within the relationship, the social worker is deeply self-reliant without the use of a professional facade. The social worker is transparent to the client, the client sees him in a relationship in which he really is. Congruence makes it easier for a client to trust a social worker.

\section{Crisis intervention in the practice of social worker with at-risk youth}

The most common and most serious manifestations that characterize the crisis are that the crisis will come unexpectedly out of nothing, has a sinister character, is associated with a loss (life, or injury), and makes people aware of their values and goals, creating fear, anxiety and helplessness that require quick decision making.

1. Every crisis brings with it destabilization, both within the psychological and the social level.

2. The crisis is accompanied by increased controllability, manifested by behavioral changes - it is necessary to stabilize them.

3. If the causes are small, reckless words can lead to aggression and may have consequences for the future.

The term crisis is defined by Šrobárová (2016) as a certain turning point, a turning point in which the individual was. The situation, which, although initially unfavorable, ultimately opens up new possibilities and perspectives on the current world and status. Crisis intervention is also a specialized help to a person who has experienced or is in crisis. According to Šrobárová (2014), the crisis intervention is a method that represents an acute intervention of a professional client who finds himself in a crisis and is unable to solve his situation, cannot cope with the problem and aims to eliminate threats and create forms of help that cover emotional support, security, socio-legal assistance. Employees of socio-legal protection of children and social guardianship most often encounter the following types of crisis measures: 
- regulation of parental responsibility (custody of a child, adjustment of contact, determination of maintenance, determination of name, determination and denial of paternity, approval of legal act, granting of parental rights to minors, duty to inform, disagreement of parents);

- regulation of parental responsibility with an international element (parental abductions, unjustified relocation of children, international adoptions, unaccompanied underage);

- Child abuse and neglect syndrome or ill-treatment (CAN);

- Educational measures (warning, supervision, restriction, obligation to submit to social counseling, warning, obligation to attend specialized facilities);

- alternative care (alternative care, foster care, institutional care). (Hardy et al., 2012).

Within the study area, we focused on the perception of crisis intervention and parole field social workers of social protection and guardianship of youth at risk. While the object of the research was social curators and field social workers of social protection and guardianship, and the main goal was to find out the perception of crisis intervention by social curators and field social workers working at the Department of Socio-Legal Protection and Social Guardianship. The research was carried out using a quantitative strategy using a customized questionnaire. There were 29 field social workers working at the SPoCaSC department. 24 were social curators, and 5 were the other. The option "other" was chosen by 6 collision guardians, 3 psychologists, 5 social workers, 2 field social workers, SPoCaSC Head of Unit. The target group of respondents was mostly children and families and to a lesser extent also natural persons. The vast majority of 53 respondents answered the question whether they perceive the legislative limitation of the execution of crisis intervention with the following result: 30 can't judge, 9 replied that yes and 14 replied no.

Those who perceived a legislative restriction cited as the reasons the following: bureaucracy, administrative burdens, lack of networking - lack of actors in the region. The gaps in Slovak legislation are set so that the social worker is de facto only an administrator. One of problems related to the protection of victims against the aggressor (the victim is usually punished to escape from the proximity of the aggressor as he remains in his environment until convicted). The; lack of competence in accordance with the SPO Act, courts do not use more vigorous possibilities within their competences, fines, penalties in case of non-respect e.g. hey will order an educational measure and parents will not respect it and nothing will change; in some cases, it can be predicted, respectively. To see that certain measures will not be effective in the given case, but we cannot omit them for the legislative prescribed procedure; a complicated procedure, there is a need for quick, prudent action and procedures.

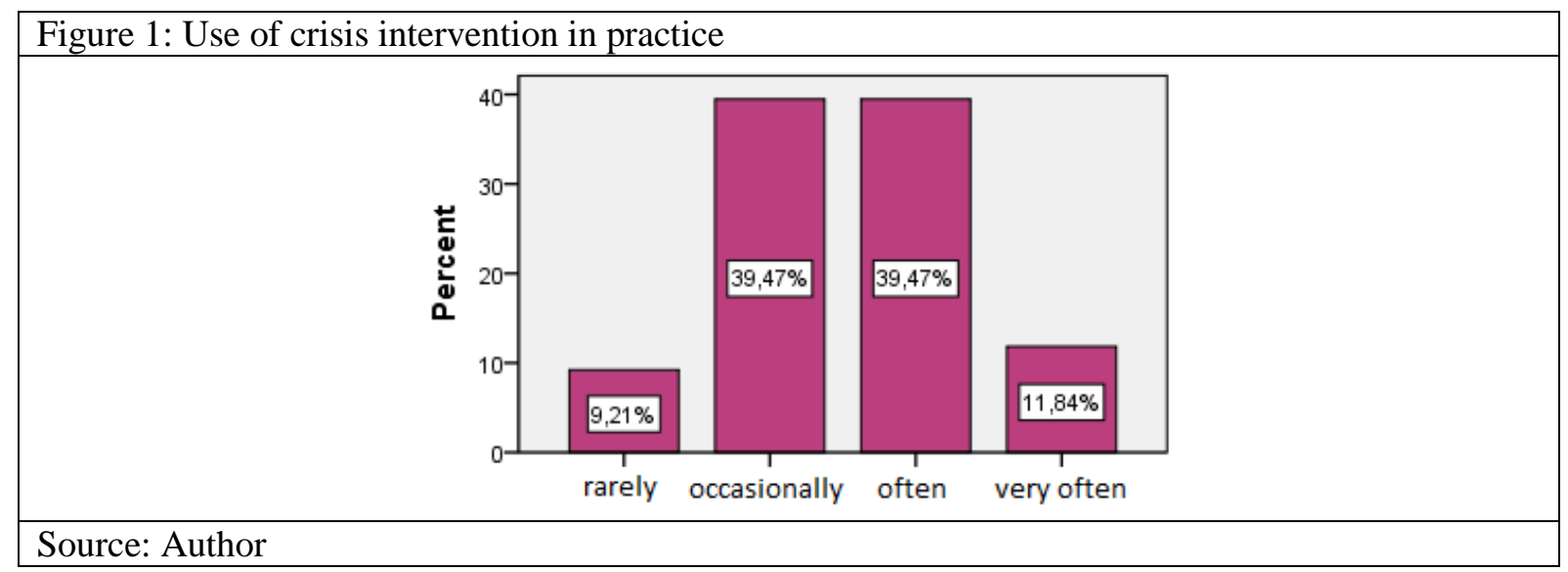

Figure 1 shows respondents' average responses to how often the techniques, methods, principles and services of crisis intervention are used. The scale was from $1=$ rarely, to $5=$ very often. As shown in the graph, on average they most often use counseling and motivational interview (often and very often). They use less social support, social diagnosis, threat reduction, networks, social assistance, ventilation, education, stabilization, rationalization and preventive activities (sometimes often). They also make less use of distribution, elimination of violence, projection, modification, exclusion, debriefing, centering and internet counseling (rarely and occasionally).

Our results show that respondents, on average, most often come into contact with their family rehabilitation, crime, divorce, delinquency, addiction, child exclusion, loss of home and CAN syndrome 
(sometimes and often). They are less confronted with infidelity, domestic violence, (material and functional, relationship, intrapsychic) loss, crime victims, self-harm and suicidal attempts (rarely and occasionally). They are also less likely to work with survivors and suicides (never and rarely).

Research question 1: Is there a significant difference in the use of techniques, methods, principles and services of crisis intervention relative to the job position? Research question 1 was verified through the Kruskal Wallis Test for three or more independent selections. The result is shown in Table 3. The significance value is lower than the determined significance level $(p=0.005)$ only in the ventilation and exclusion method. The use of other crisis intervention methods is similar among the respondent groups.

\begin{tabular}{|l|l|l|l|l|}
\hline \multicolumn{5}{|l|}{ Table 3 Differences in the use of crisis intervention techniques, } \\
\hline & $\begin{array}{l}\text { Chi- } \\
\text { Square }\end{array}$ & df & $\begin{array}{l}\text { Asymp. } \\
\text { Sig. }\end{array}$ \\
\hline Ventilation & $\mathbf{1 2 . 2 6 8}$ & $\mathbf{2}$ & $\mathbf{0 . 0 0 2}$ \\
\hline Projection & 5.662 & 2 & 0.059 \\
\hline Social support - search, contact & 4.845 & 2 & 0.089 \\
\hline Network & 3.281 & 2 & 0.194 \\
\hline Modifications & 1.374 & 2 & 0.503 \\
\hline Exemption & $\mathbf{1 0 . 2 6 8}$ & $\mathbf{2}$ & $\mathbf{0 . 0 0 6}$ \\
\hline Education & 1.985 & 2 & 0.371 \\
\hline Elimination of violence & 4.656 & 2 & 0.097 \\
\hline Counseling & 1.053 & 2 & 0.591 \\
\hline Threat reduction & 0.970 & 2 & 0.616 \\
\hline Motivational interview & 1.277 & 2 & 0.528 \\
\hline Social assistance & 1.206 & 2 & 0.547 \\
\hline Social diagnostics & 0.804 & 2 & 0.669 \\
\hline Distribution & 0.710 & 2 & 0.701 \\
\hline Debriefing & 1.473 & 2 & 0.479 \\
\hline Centering & 2.072 & 2 & 0.355 \\
\hline Condition stabilization & 1.266 & 2 & 0.531 \\
\hline Rationalization & 0.023 & 2 & 0.988 \\
\hline Internet counseling & 0.949 & 2 & 0.622 \\
\hline Preventive activities & 5.635 & 2 & 0.060 \\
\hline Source: Author & & \\
\hline
\end{tabular}

The above table shows that exemptions are more often used by social curators and, at least, by respondents who have said "other" and the method of ventilation is most often used by field social workers and least often by social curators (these differences are statistically significant).

Another research question was whether there is a link between the use of crisis intervention in practice and the resolution of individual social problems?

We verified this through the Spearman's correlation coefficient. There was a statistically significant, positive relationship:

1. A strong level exists between the use of crisis intervention and family remediation $(r=$ $0.410, \mathrm{p}=0.000$ ). This means that respondents who are more sophisticated in their practice of family remediation are more likely to use crisis intervention;

2. a weak level exists between the use of crisis intervention and crime $(r=0.252, p=0.028)$. This means that respondents who are more likely to deal with crime in their practice are more likely to use crisis intervention;

3. moderate strength exists between the use of crisis intervention and delinquency $(r=0.314$, $\mathrm{p}=0.006$ ). This means that respondents who are more likely to deal with delinquency in their practice are more likely to use crisis intervention;

4. a weak level exists between the use of crisis intervention and suicide resolution $(r=0.227$, $\mathrm{p}=0.049$ ). This means that respondents who are more involved in suicide in their practice are more likely to use crisis intervention;

5. moderate strength exists between the use of crisis intervention and the resolution of dependencies $(r=0.325, p=0.004)$. This means that respondents who are more dependent on addiction in their practice are more likely to use crisis intervention. 


\section{Conclusion}

Social curators are met (within the Slovak Republic) with various social problems. They use certain techniques, principles and services of crisis intervention for each problem. This sub-objective has shown us precisely the techniques, methods, principles and services of crisis intervention according to the social problem solved by social workers.

As part of the research question, we investigated differences in the use of techniques, methods, principles and services of crisis intervention among workers working as field social workers, social curators, and respondents who classified themselves as others. Based on the results of the relevant statistical test, we can conclude that differences were observed only in ventilation and exclusion.

Ventilation is more frequently used by field social workers, then by others and, to then a lesser extent, social curators. On the contrary, exemption is most often used by social curators, less often by field social workers and least by those who have said others. This also depends on the function the social worker performs. "Social curators and field social workers encounter multiple social problems in their work. Differences in the use of techniques, methods, principles and crisis intervention services are possible due to their function. "

Based on the results we can say that respondents often find the solution through family redevelopment, crime resolution, divorce and dependency. Sometimes they also encounter the exclusion of a child from a natural family environment, home loss, CAN syndrome, infidelity, domestic violence, material, functional, relationship, intrapsychic and role loss, crime victims, self-harm. Rarely they are faced with a suicide attempt and work with survivors. In our opinion, social problems are closely related to practice. Depending on what problems social workers often have, it results in experience and whether they need further education (if workers start to deal with other problems within the Slovak Republic). They encounter CAN syndrome and domestic violence in comparison with other watch groups, and social curators are more likely to encounter crime resolution and the removal of a child with a natural family environment compared to other monitored groups of professions. In conclusion, we can say that a risky client is any social client who is at risk, from his behavior and actions, or from the behavior and actions of another individual, group, or company. The risk of such a client may be the cause of his failure in the company. That is why it is necessary to constantly increase the qualification of social curators in crisis intervention in working with at-risk youth and also to expand the portfolio of methods and techniques for different types of social problems.

\section{References}

Bednárik, R. (2015). Stav sociálnej ochrany na Slovensku (Situácia k 1. januáru 2015) [The State of Social Protection in Slovakia (Situation to $1^{\text {st }}$ of Janaáry)]. Bratislava: Labor and Family Research Institute.

Gabura, J. (2012). Teória rodiny a proces práce s rodinou [Family Theory and the Family Work Process]. Bratislava: IRIS, Publishing and Printing, s.r.

Hardy, M., Brišáková, J., Pavelová L., Tomka M. (2012). Metódy sociálnej práce s rodinou. Zborník z vedeckej konferencie s medzinárodnou účastou [Methods of social work with family. Proceedings of a scientific conference with international participation]. Bratislava: VŠZaSP sv. Alžbety,

Mátel, A., Schavel, M., Drexlerová, B. (2013). Sociálno-ekologické perspektívy ako teoretická platforma pre riešenie sociálno-ekonomických problémov v spoločnosti. In Sociální a vzdělanostní souvislosti finanční gramotnosti [Social-ecological perspectives as a theoretical platform for solving socio-economic problems in society. In Social and educational context of financial literacy.] Prague: BIVŠ.

Ministry of Labor, Social Affairs and Family. (2016). Správa o sociálnej situácii obyvatel'stva SR za rok 2016 [Report on the social situation of the Slovak population for the year 2016]. Bratislava: Ministry of Labor in Slovakia.

Šrobárová, S. (2016). Krízová intervencia v multidisciplinárnom ponímaní v riešení vybraných akútnych sociálnych problémov [Crisis Intervention in Multidisciplinary Conception in Solving Selected Acute Social Problems]. Ružomberok: Verbum - Publishing House of the Catholic University in Ružomberok. 